\title{
KESIAPAN DESA DALAM PENERAPAN E-GOVERNMENT (Studi Perbandingan di Desa Semaya dan Desa Pegiringan Kabupaten Pemalang)
}

\author{
Subhan, Arif Budy Pratama \\ Universitas Tidar
}

\author{
*Coressponding Author. Email : subhan.han231996@gmail.com
}

\begin{abstract}
Many government organizations have implemented e-government. The use of information and communication technology in governments business process spreads only in the central and local government but also in the village level. One of the most important issues in e-government implementation is institutional readiness. This paper aims to examine village government readiness through comparative analysis. The study is located in the Pemalang regency, one of the most active regencies in developing e-government in the village level. Semaya and Pegiringan Village was chosen as research loci since they represented successful and un-succesful outcome of egovernment initiatives. To address the research objective, a case study was conducted. The data was drawn from in-depth interview, observation on website and business process, and relevant documents. We find that e-government readiness in the village level can be assessed from the following aspects: data system, regulatory framework, institutional arrangement, human resources, technological infrastructure, and strategic thinking of leadership. Some policy implications can be drawn to improve the e-government readiness in village level.
\end{abstract}

Keywords : e-government, e-government readiness, village government

\begin{abstract}
Abstrak
Implementasi e-government tidak hanya dilakukan oleh Pemerintah Pusat dan Pemerintah Daerah, tetapi juga dilakukan oleh Pemerintah Desa. Salah satu faktor penting dalam implementasi e-government adalah kesiapan institusi dalam menjalankan kebijakan egovernment. Tulisan ini bertujuan untuk membahas kesiapan penerapan e-government pada pemerintahan di level desa dengan menggunakan perspektif perbandingan. Lokasi penelitian adalah dua desa di Kabupaten Pemalang sebagai salah satu Kabupaten yang aktif dengan pengembangan internet di desa. Desa Semaya dan Desa Pegiringan dipilih sebagai lokus penelitian karena mewakili desa yang relatif berhasil dan kurang berhasil dalam pengembangan e-government di level desa. Penelitian ini menggunakan metode kulatitatif dengan strategi studi kasus. Teknik pengumpulan data dilakukan dengan wawancara, dokumentasi dan observasi. Hasil penelitian menunjukkan bahwa aspek sistem data, landasan hukum, kelembagaan, sumber daya manusia, infrastruktur teknologi serta kepemimpinan dan pemikiran strategis berperan dalam kesiapan penerapan e-government. Beberapa implikasi kebijakan dapat dirumuskan untuk meningkatkan kesiapan Pemerintah Desa dalam implementasi e-government.
\end{abstract}

Kata Kunci: Kesiapan, electronic government, pemerintah desa. 
Jurnal Administrasi Negara

ISSN : 2598-4039 (Online)

ISSN : 2302-2231 (Print)
Subhan, Arif Budy Pratama

Universitas Tidar Magelang

\section{PENDAHULUAN}

Dewasa ini tidak dapat dipungkiri bahwa kemajuan teknologi menjadi sumber daya utama bagi organisasi dalam meningkatkan kualitas layanan secara optimal serta meningkatkan daya saing dalam era globaliasi (Kodarisman \& Nugroho, 2013, p. 24). Perkembangan teknologi mendorong agar pemerintah tidak hanya menyelenggarakan layanan publik secara konvensional sebab telah hadir model pelayanan publik yang dilakukan melalui e-government. Seperti yang diungkapkan Ndou (2004) bahwa penerapan e-government memberikan banyak manfaat bagi pemerintah, masyarakat dan dunia bisnis. Egovernment memudahkan sektor bisnis, warga dan pemerintah untuk memperoleh informasi yang disediakan tanpa batas serta meningkatkan kualitas layanan yang ada (Alshehri \& Drew, 2010). Inisiatif pelaksanaan e-government di Indonesia dimulai sejak dikeluarkannya Instruksi Presiden No. Inpres No 3 Tahun 2003 tentang kebijakan dan strategi nasional pengembangan e-government.

Data yang dirilis oleh United Nation mengenai E-Government Development Index (EGDI) tahun 2018 menempatkan Indonesia pada peringkat ke-107 EGDI. Posisi ini meningkat 9 peringkat dibandingkan tahun 2016 yang menduduki peringkat 116. Akan tetapi untuk kawasan Asia Tenggara, peringkat Indonesia masih sama dengan tahun sebelumnya yakni menduduki peringkat ke-7. Indonesia masih berada dibawah negara seperti Singapura, Malaysia, Brunei Darussalam, Thailand, Filipina dan Vietnam. Kemudian untuk nilai ratarata EDGI, Indonesia juga masih berada dibawah rata-rata untuk regional Asia Tenggara(Widowati, 2018).

E-government menjadi inovasi baru bagi pemerintah untuk mempermudah proses penyelenggaraan pemerintahan demi memberikan pelayanan prima terhadap masyarakat. Indrajit (2001) mengatakan bahwa e-government menjadi pengembangan baru yang mengubah interaksi masyarakat dengan pemerintah maupun pemerintah dengan dunia bisnis (Latif, Wahyu, \& Surjono, 2012). E-government didefinisikan oleh World Bank sebagai pemanfaatan teknologi informasi oleh lembaga pemerintah yang dapat mentransformasikan hubungan antara pemerintah dengan masyarakat, dunia bisnis maupun dengan lembaga pemerintahan lain (Napitupulu, 2015).

Praktik e-government di Kabupaten Pemalang relatif berkembang. Hal tersebut dibuktikan dengan penggunaan $e$-voting dalam pemilihan kepala desa tahun 2018 di Kabupaten Pemalang. Pemerintah Kabupaten Pemalang juga berinovasi dalam penyediaan layanan bagi masyarakat berupa penggunaan website desa (e-village). Penerapan $e$ village menjadi representasi pelaksanaan regulasi tentang e-government di Indonesia. Lebih lanjut, e-village didukung dengan adanya UU No. 6 tahun 2014 tentang Desa yang mengisyaratkan untuk menyediakan informasi perencanaan pembangunan Kabupaten/Kota untuk Desa. Selain itu, pengembangan e-government khususnya Jawa Tengah juga diperkuat dengan adanya PERGUB No. 47 Tahun 2016 tentang Pedoman Pengembangan Sistem Informasi Desa di Provinsi Jawa Tengah.

Berbagai studi atau penelitian telah banyak dilakukan untuk mengkaji tentang perkembangan e-government. Studi tersebut hanya fokus pada pemerintahan di tingkat kabupaten, sedangkan untuk studi e-government pada level desa belum banyak penelitian dilakukan. Berbagai studi tersebut diantaranya faktor atau 
Jurnal Administrasi Negara

ISSN : 2598-4039 (Online)

ISSN : 2302-2231 (Print)
Subhan, Arif Budy Pratama

Universitas Tidar Magelang elemen sukses pengembangan $e$ government (Kodarisman \& Nugroho, 2013). Beberapa penelitian juga berfokus pada kebijakan e-government (Kurniasih, Fidowaty, \& Sukaesih, 2013;Rahmawati \& Firman, 2017) serta outcome dari pelaksanaan e-government (Aprizal \& Purba, 2013;Abadi, Prajarto, \& Guntoro, 2014) Beberapa penelitian tersebut belum banyak penelitian yang memfokuskan pada kesiapan penerapan e-government. Berbeda dengan beberapa penelitian tersebut, penelitian ini akan memfokuskan kajiannya mengenai kesiapan desa dalam menerapkan $e$ government dengan perspektif perbandingan.

Park (2014) mengatakan kegagalan dalam pengembangan e-government seringkali terjadi sehingga diperlukan $e$ government readiness sebelum mengembangkan e-government itu (Sukarso, Rokhman, \& Rosyadi, 2017) . Sementara kesiapan E-government dirumuskan UN (United Nation) sebagai kemampuan pemerintah dalam memanfaatkan teknologi informasi dan komunikasi untuk menyediakan akses dan inclusion (partisipasi) bagi masyarakatnya (Wijaya \& Surendro, 2006). Harvard University memberikan batasan mengenai e-readiness pada tingkat dimana sebuah komunitas siap untuk ikut berpartisipasi dalam jaringan dunia (Alaaraj \& Ibrahim, 2014). Pendapat lain mengenai e-readiness datang dari Lou (2010), bahwa $e$ readiness adalah tingkat dimana suatu bangsa atau ekonomi siap untuk memperoleh manfaat dengan adanya ekonomi digital.

Berdasarkan beberapa pemahaman mengenai kesiapan e-government, maka dapat disimpulkan bahwa e-government readiness merupakan kemampuan pemerintah dan warganya untuk memanfaatkan potensi teknologi informasi dan komunikasi dalam penyelenggaraan pemerintahan. Dengan demikian dapat kita ketahui bahwa kesiapan e-government tersebut terdiri dari sisi provider (pemerintah dan vendor) serta user (masyarakat). Kemudian penelitian ini akan memfokuskan kajiannya hanya dari sisi pemerintah saja.

Kemudian untuk melihat kesiapan dari e-government ada beberapa kerangka yang digunakan untuk mengukur hal tersebut. Wisnujaya dan Surendro (2006) dalam (Susanto, 2011) membagi kerangka e-government readiness menjadi dua, yaitu sudut pandang dari pemerintah (government e-readiness) dan masyarakat atau pengguna (user/citizen e-readiness). Faktor-faktor yang berhubugan dengan e-government readiness meliputi: a)E-leadership: berkaitan dengan prioritas dan inisitaif yang diberikan pimpinan terhadap pelaksanaan e-government. b)Culture: berkaitan dengan penerimaan pegawai pemerintah dalam menggunakan teknologi informasi dan komunikasi. c)Human resources: Aspek ini menyangkut kemampuan koginitif dan kemampuan teknis dalam penggunaan teknologi informasi dan komunikasi. d)Egovernance: Aspek yang menyangkut tata kelola e-government. f) ICT infrastructure: ketersediaan infrastruktur teknologi. g)Business climate: Aspek ini menyangkut kondisi pasar, regulasi dan sistem pasar yang berhubungan dengan ketersediaan hardware dan software. Sedangkan dari sudut pandang pengguna atau masyarakat, faktor-faktor tersebut meliputi faktor budaya adopsi teknologi dalam masyarakat, kapasitas sumber daya manusia (ICT literacy), infrastruktur teknologi yang dimiliki atau sampai pada masyarakat, lingkungan bisnis yang 
mempengaruhi masyarakat dan pendapatan atau penghasilan yang mempengaruhi belanja masyarakat.

\section{Kemudian The Economist}

Intellegence Unit (EIU) memberikan beberapa kerangka untuk mengukur sejauhmana kesiapan pasar mampu memanfaatkan peluang dari internet dengan mempertimbangkan berbagai faktor, mulai dari kualitas infrastruktur untuk mewujudkan ambisi pemerintah serta sejauhmana internet mampu menciptakan efisiensi. Kerangka tersebut terdiri dari: Konektivitas dan infrastruktur teknologi (25\%), lingkungan bisnis (20\%), konsumen dan adopsi bisnis $(20 \%)$, sosial dan infrastruktur budaya (15\%), hukum dan kebijakan lingkungan (15\%), mendukung e-services $(5 \%)$ (Beig, Montazer, \& Ghavamifar, 2007).

Heeks (2001) memberikan enam kerangka kesiapan yang dapat digunakan oleh pemerintah negara berkembang untuk menilai sejauh mana kesiapan pemerintah mereka dalam mewujudkan e-govenrnance. Adapun indikator tersebut adalah:

\section{Sistem data}

Hal ini berkaitan dengan sistem manajemen, pencatatan dan proses kerja dapat menyediakan kuantitas dan kualitas data yang mendukung. Sebab kebanyakan negara berkembang, memiliki kualitas data dan keamanan data sangat buruk.

\section{Landasan Hukum}

Berkaitan dengan adanya undang-undang dan peraturan yang dapat mendukung pelaksanaan e-government.

\section{Kelembagaan}

Penerapan pemerintah berbasis IT hanya dapat berkembang apabila ada lembaga khusus yang berfokus untuk menangani e-government. Hal tersebut sebagai bentuk kesadaran dan sarana memfasilitasi pelaksanaan e-government. Sebab di beberapa negara, tidak ada lembaga yang mengkoordinasi, memimpin serta mendorong perkembangan e-government.

\section{Sumber daya manusia}

Kesiapan dari sumber daya manusia juga harus diperhatikan, kaintannya dengan sikap, pengetahuan, maupun keterampilan utamanya dalam sektor publik untuk memulai, melaksanakan serta mendukung pelaksanaan $e$ government.

\section{Infrastruktur teknologi}

Sudah bukan rahasia lagi apabila keberhasilan e-government tidak dapat lepas dari infrastruktur teknologi yang ada. Namun faktanya di beberapa negara berkembang masih jauh dari komputerisasi dan infrastruktur telekomunikasi yang mumpuni.

\section{Kepemimpinan dan pemikiran strategis}

Pra-kondisi yang tidak kalah penting yakni peran pemimpin yang mempunyai visi untuk mewujudkan e-government. Pemimpin yang mempunyai langkah strategis guna mewujudkan e-government dapat meminimalisir hambatan dalam implementasi e-governement. Sebaliknya, upaya untuk menuju pemerintah yang lebih baik melalui e-government hanya akan menjadi angan-angan apabila tidak ada visi dan sikap kepemimpinan yang memberikan perhatian pada $e$ government.

Setelah mengetahui berbagai model pengukuran kesiapan e-readiness di atas, maka penting untuk memilih kerangka analisis yang akan digunakan untuk membandingkan kesiapan penerapan website desa di desa Semaya dan desa 
Jurnal Administrasi Negara

ISSN : 2598-4039 (Online)

ISSN : 2302-2231 (Print)
Subhan, Arif Budy Pratama

Universitas Tidar Magelang
Pegiringan. Penelitian ini menggunakan kerangka e-readiness yang disampaikan oleh Heeks karena model tersebut telah banyak digunakan untuk menganalisis kesiapan e-governemnt di negara berkembang. Indonesia adalah salah satu negara berkembang dengan peringkat $e$ government ke-106 menurut EDGI.

Dalam penelitian yang dilakukan oleh Hwang dan Syamsudin (2008) menunjukkan bahwa implementasi $e$ government masih ditemui beberapa hambatan, khususnya pada tingkat pemerintah daerah (Rahman, 2011). Kasus yang sama juga terjadi di Desa Semaya dan Desa Pegiringan, meskipun sudah berjalan beberapa waktu, tetapi fakta yang ada menunjukkan bahwa pengelolaan website kedua desa terdapat perbedaan. Informasi yang ada dalam website desa Semaya tergolong masih sangat terbatas sedangkan website desa Pegiringan sudah cukup lengkap serta interaktif.

Selain itu, perbedaan juga terlihat dari pengahargaan yang sudah diperoleh desa pegiringan. Tercatat dalam lomba website desa yang diselenggarakan oleh pemerintah Kabupaten Pemalang berhasil memperoleh peringkat ke dua pada tahun 2016 dan peringkat pertama pada tahun 2017. Bahkan baru-baru ini website pegiringan.desa.id meraih penghargaan ID Website Award 2018 kategori desa yang diselenggarakan oleh Pengelola Nama Domain Internet Indonesia (PANDI) (Pegiringan.desa.id, 2018). Berdasarkan uraian tersebut maka penelitian ini bertujuan untuk membandingkan dan menganalisa kesiapan penerapan website desa di desa Semaya dan desa Pegiringan yang masih dalam satu wilayah administrasi.

\section{METODE PENELITIAN}

Metode yang digunakan dalam penelitian ini adalah metode kualitatif. Strategi yang digunakan yaitu dengan studi kasus di mana didalamnya peneliti menyelidiki secara cermat suatu program, peristiwa, aktivitas, proses atau sekelompok individu (Creswell, 2013). Studi kasus dipilih dengan pertimbangan dapat mengetahui secara mendalam suatu fenomena.

Pendekatanan lain yang digunakan adalah pendekatan komparatif yakni dengan melihat persamaan dan perbedaan dari fenomena yang ada. Menurut Rihoux \& Ragin (2009) dalam (Pratama, 2017a) berpendapat bahwa penalaran manusia sangat didorong oleh perbandingan sehingga menyarankan bahwa perbandingan adalah pendekatan kunci dalam setiap upaya ilmiah. Pemahaman terhadap sebuah fenomena dapat dilakukan dengan mengenali dan membandingkan satu dengan yang lain.

Secara umum pendekatan yang digunakan dalam studi komparatif ada lima (Fleming, 1970; Hospkin, 2010; Lim, 2010; Peters, 1998) dalam (Pratama, 2017a):

a. Most Similar System (MSS), dimana membandingkan tempat atau negara yang memiliki fitur yang sama.

b. Most Different System (MDS), digunakan untuk membandingkan tempat atau negara-negara yang memiliki fitur yang berbeda kecuali tema yang sedang diselidiki.

c. Generally Similar Group (GSG), yakni dengan membandingkan sekelompok negara homogen sehubungan dengan kesamaan kelompok mereka. Desain ini sama dengan desain MSS tetapi tanpa mode MSS yang ketat.

d. Structural Functional System (SFS), desain perbandingan yang 
menekankan pada pendekatan struktur fungsional seperti struktur politik, budaya, dan proses pengambilan keputusan.

e. Global Statistical Analysis (GSA), desain yang membandingkan variabel statistik di negara yang diteliti.

Mengingat perbedaan karakteristik implementasi e-governent di Desa Semaya dan Desa Pegiringan maka penelitian ini menggunakan desain Most Different System (MDS).

Lokus penelitian dilakukan pada dua desa di Kabupaten Pemalang, yaitu Desa Pegiringan dan Desa Semaya yang sudah menerapkan website desa. Fokus kajian dalam penelitian ini yaitu mengacu pada 6 (enam) kerangka kesiapan Heek (2001) yang meliputi sistem data, landasan hukum, kelembagaan, sumber daya manusia, infrastruktur teknologi serta kepemimpinan dan pemikiran strategis. Lebih jauh, penelitian ini juga memfokuskaan kajiannya mengenai implikasi kebijakan yang dapat diambil oleh pemerintah desa.

Adapun sumber data penelitian terdiri dari sumber data primer dan data sekunder. Data primer diperoleh dari hasil wawancara langsung dengan infroman di lapangan dan data sekunder Data sekunder diperoleh dari bahan kepustakaan yang relevan berupa artikel dalam website desa.

\section{HASIL DAN PEMBAHASAN \\ Perbandingan Kesiapan Penerapan $E$ - Government di Desa Pegiringan dan Desa Semaya \\ Sistem Data}

Keberhasilan penerapan e-government harus di dukung dengan ketersediaan data yang baik. Secara umum sistem pencatatan atau manajemen data dari kedua desa dapat dikatakan relatif siap untuk menyokong penerapan $e$ government di pemerintah desa baik data kependudukan, keuangan maupun data yang lain. Data-data tersebut sudah tersedia di masing-masing kantor desa. Lebih lanjut, untuk ketersedian data di Desa Pegiringan sendiri sudah disiapkan oleh masing-masing Kasi sesuai dengan tugas pokok dan fungsinya.

Perbedaan baru terlihat pada ketersedian data-data tersebut di website masing-masing desa. Data yang termuat dalam website Desa Semaya relatif sangat terbatas dimana hanya tersedia profil desa dan struktur organisasi Pemerintah Desa Semaya. Minimnya ketersedian data ini disebabkan penginputan data yang dilakukan ke dalam website belum dilakukan secara keseluruhan. Dapat dikatakan bahwa perkembangan $e$ government di Desa Semaya seperti dikutip dari West (2004) dalam (Pratama, 2017b) baru masuk pada tahap the billboard stage yakni berupa penggunaan website oleh pemerintah yang hanya memungkinkan adanya penyampaian informasi kepada masyarakat yang bersifat satu arah sehingga tidak dapat terjadi interaksi antara penyedia dan pengguna. Akses masyarakat terhadap data-data lain juga masih dilakukan secara konvensional karena kurangnya ketersediaan data di website.

Hal ini sangat berbeda dengan kondisi website Desa Pegiringan, dimana data yang disediakan sudah sangat lengkap misalnya seperti data keuangan, demografi dan sebagainya. Selain itu, penggunaan website juga bukan hanya sebagai penyedia informasi saja. Pegiringan.id menjadi platform yang juga dikembangkan untuk dapat menyediakan layanan bagi masayarakat setempat. Pelayanan yang disediakan dibagi menjadi dua bagian yaitu layanan 
Jurnal Administrasi Negara

ISSN : 2598-4039 (Online)

ISSN : 2302-2231 (Print)
Subhan, Arif Budy Pratama

Universitas Tidar Magelang dasar dan sosial serta layanan online terintegrasi.

Lebih lanjut, penggunaan tanda tangan digital juga sudah digunakan untuk mempercepat pemberian layanan bagi masyarakat. Perkembangan e-government di Desa Pegiringan sendiri sudah masuk pada tahap government portal seperti yang disampaikan oleh West (2004) dalam(Pratama, 2017b), yakni fasilitas online yang disediakan oleh pemerintah. Seluruh unit layanan sudah terintegrasi dalam satu portal layanan sehingga semua layanan yang dibutuhkan dapat diakses dalam satu platform layanan online. Hal ini juga yang mempengaruhi website desa Pegiringan dalam memperoleh penghargaan baik di tingkat Kabupaten maupun di level nasional seperti penghargaan dari PANDI dan IWA tahun 2018.

\section{Landasan Hukum}

Penerapan e-government pada level pemerintah desa tidak dapat lepas dengan adanya payung hukum yang melatar belakangi munculnya hal ini. Melalui sifat regulasi yang memaksa maka secara tidak langsung menjadi sebuah kewajiban bagi pemerintah desa untuk dapat menjalankan kebijakan tersebut. Dalam kasus ini penerapan e-government di Desa Semaya dan Desa Pegiringan mempunyai landasan hukum sama yang mengacu pada Undang-Undang No. 6 tahun 2014 tentang desa yang memberikan kewajiban bagi desa untuk menyediakan sistem informasi yang meliputi data desa, data pembangunan desa, kawasan perdesaan, serta informasi lain yang berkaitan dengan pembangunan desa dan pembangungan kawasan perdesaan. Selain itu, penerapan tersebut juga diperkuat dengan Pegub Nomor 47 tahun 2017 tentang Pedoman Pengembangan Sistem Informasi Desa di Provinsi Jawa Tengah.
Hal ini juga diikuti dengan adanya semangat pelaksanaan e-government dari Pemerintah Kabupaten Pemalang agar desa dapat menggunakan teknologi informasi dalam penyelenggaraan pemerintahan. Meskipun belum ada peraturan tertulis yang dikeluarkan oleh Pemerintah Kabupaten terkait dengan penerapan e-gov tersebut. selanjutnya, dari sisi pemahaman secara mendalam baik dari pemerintah Desa Semaya maupun Desa Pegiringan terhadap landasan hukum ini relatif masih kurang. Sehingga masih diperlukan sosialisasi mengenai payung hukum dari pelakasanaan e-government agar membentuk satu tujuan yang sama.

\section{Kelembagaan}

Penerapan pemerintah berbasis IT secara proporsional sebenarnya didukung dengan adanya ketersediaan lembaga yang dapat mengkoordinasi, memimpin serta mendorong perkembangan $e$ government. Hal tersebut menjadi bentuk dari kesadaran pemerintah untuk mengoptimalkan implementasi e-gove. Pengelolaan dan pengembangan $e$ government di Desa Semaya dan Desa Pegiringan dibebankan kepada Kader Pemberdayaan Masyarakat Desa (KPMD). Salah satunya merupakan kader IT yang secara khusus mengelola website di masing-masing desa.

Apabila dilihat dalam Peraturan Menteri Desa PDTT Nomor 3 Tahun 2015 tentang pendamping desa maka tugas dari KPMD adalah untuk menumbuhkan prakarsa dan mengembangkan, menggerakkan prakarsa, partisipasi dan swadaya gotong royong. Sehingga tanggung jawab yang diberikan kepada KPMD untuk dapat mengelola dan mengembang $e$ government mungkin masih kurang tepat. 
Jurnal Administrasi Negara

ISSN : 2598-4039 (Online)

ISSN : 2302-2231 (Print)
Subhan, Arif Budy Pratama

Universitas Tidar Magelang
Proses rekrutmen pengelola di Desa Semaya dan Desa Pegiringan belum menggunakan sistem yang profesional melalui merit sistem. Dalam hal ini Kepala Desa sebagai pemegang kekuasaan tertinggi di level Pemerintah Desa memiliki wewenang untuk menentukan seseorang untuk menjadi pengelola website di masing-masing desa. Legalitas dari pengelola tersebut diperoleh melalui Surat Keputusan yang dikeluarkan oleh Kepala Desa. Dari sisi lain, sistem perekrutan yang demikian sebenarnya mengandung resiko ketika pengelola yang sudah ditentukan tidak sesuai dengan klasifikasi yang dibutuhkan.

\section{Sumber Daya Manusia}

Kapasitas sumber daya manusia yang baik sangat dibutuhkan untuk dapat menerapkan e-government dalam sebuah organisasi publik agar dapat sesuai dengan asas manfaat yang diinginkan. Pengelolaan website Desa Semaya hanya dilakukan oleh satu orang. Artinya semua tugas mulai dari pengisian konten dan pengembangan website hanya dibebankan terhadap satu orang saja. Sehingga implementasi e-government di Desa ini relatif masih kurang baik.. Secara latar belakang pendidikan, pengelola juga bukan merupakan ahli dalam bidang informasi dan teknologi. Akibatnya, selama ini pengetahuan dari pengelola dalam mengoperasikan website relatif masih terbatas.

Peningkatan kompetensi pengelola dilakukan dengan mengikuti pelatihanpelatihan yang diselenggarakan Pemerintah Kabupaten Pemalang serta instansi-instansi terkait. Peningkatan kompetensi di Desa Semaya sendiri hanya bertumpu pada pelatihan-pelatihan tersebut, karena pelatihan yang dilakukan oleh internal Pemerintah Desa belum pernah dilaksanakan. Masih diperlukan beberapa training tambahan untuk dapat menambah literacy dari pengelola mengenai pengembangan serta pemanfaatan website secara lebih jauh.

Berbeda dengan Desa Pegiringan, awalnya pengelolaan website dibebankan terhadap satu orang sebagai admin. Akan tetapi, dalam pelaksanannya di lapangan terdapat pembagian tugas untuk mengelola. Misalnya terdapat bagian pembuatan berita, editing video, serta editing gambar untuk mengisi konten website desa. Secara kuantitas SDM, pengelolaan menjadi lebih mudah karena pengembangan tidak hanya bertumpu terhadap orang tertentu saja. Sama halnya dengan Desa Semaya, admin panel dari website Desa Pegiringan juga bukan berlatarbelakang pendidikan dalam bidang teknologi dan informasi.

Kompetensi pengelola website di Desa Pegiringan dapat dikatakan cukup baik. Hal ini karena pengetahuan tentang pengelolaan dan pengembangan website tidak hanya diperoleh melalui pelatihan secara bertahap yang dijadwalkan oleh Pemerintah Kabupaten Pemalang dan beberapa instansi terkait. Akan tetapi, diluar pelatihan tersebut pengelola juga menjalin komunikasi yang intens dengan PUSPINDES (Pusat Pemberdayaan Informatika Perdesaan) dari Kabupaten Pemalang. Hal ini tentunya menambah literacy dari pengelola website dan wujud komitmen yang kuat dari pengelola dan Pemerintah Desa Pegiringan untuk dapat mencapai tujuan e-government.

Disisi lain, proses peningkatan kompetensi dari admin didapatkan dengan pembalajaran dari mentor yang memang ahli dalam bidang teknologi dan informasi. Perbedaan pembelajaran yang diperoleh membuat kompetensi dari pengelola/admin website Desa Pegiringan relatif berbeda dengan 
Jurnal Administrasi Negara

ISSN : 2598-4039 (Online)

ISSN : 2302-2231 (Print)
Subhan, Arif Budy Pratama

Universitas Tidar Magelang beberapa desa yang lain. Selain PUSPINDES, pelatihan juga pernah dilaksanakan dengan menggandeng komunitas yang bergerak dalam bidang pengelolaan website seperti komunitas google.

\section{Infrastruktur Teknologi}

Dalam penerapan e-government di Desa Semaya, pengadaan infrastruktur teknologi pun sudah cukup baik. Pemenuhan perangkat keras komputer serta jaringan internet sudah tersedia di Kantor Desa. Namun demikian, kecepatan jaringan internet di Desa Semaya masih kurang mumpuni untuk dapat mendukung terwujudnya $e$ government yang baik. Pembangunan infrastruktur jaringan juga baru untuk pemerintah desa saja. Belum mencakup pembangunan jaringan yang dapat diakses oleh masyarakat setempat. Kurangnya kecepatan jaringan internet juga diakui menjadi salah satu hambatan penerapan e-gov di Desa Semaya. Mengingat penginputan data maupun update informasi memang membutuhkan kecepatan data yang baik. Sehingga selama ini masih menyesuaikan dengan keadaan tersebut.

Sementara upaya mewujudkan $e$ government di Desa Pegiringan diikuti dengan pengadaan infrastruktur yang relatif mumpuni. Setiap perangkat desa sudah disediakan masing-masing perangkat komputer untuk menunjang pelayanan. Tidak hanya perangkat komputer, dukungan perangkat lain seperti kamera digital untuk membuat liputan mengenai pembangunan kawasan pedesaan juga membantu pengelola untuk pembuatan konten website maupun update kegiatan pembangunan desa serta informasi-informasi penting lainnya.

Kemudian penerapan e-government di Desa Pegiringan didukung pula dengan kecepatan jaringan yang baik. Kecepatan transfer data yang mumpuni relatif membantu pengelola untuk penginputan data ke dalam website sehingga interaksi government to citizen di Desa Pegiringan dapat berjalan dengan baik. Masingmasing komputer untuk pelayanan juga sudah terintegrasi dalam jaringan tersebut. Lebih Jauh, pembangunan infrastruktur juga tidak dipusatkan di dalam kawasan Pemerintah Desa. Inisiasi pembangunan beberapa hotspot area di masing-masing Kepala Dusun sudah dilakukan dan membuka kesempatan bagi masyarakat untuk ikut serta memanfaatkan jaringan yang ada sekaligus mempermudah masyarakat untuk mengakses informasi di website desa dan menggunakan layanan lain seperti pengaduan dan sebagainya.

\section{Kepemimpinan dan Pemikiran Strategis}

Komitmen kuat seorang pemimpin dalam mewujudkan e-government dapat memperkecil hambatan-hambatan dalam implementasinya. Mengingat pemimpin berperan dalam mengarahkan organisasi publik dalam mencapai asas manfaat $e$ government. Pemikiran atau gagasangagasan pemimpin juga diperlukan agar dapat memunculkan inovasi-inovasi baru dalam implementasi e-governent. Dengan semakin berkembangnya teknologi maka penggunaan teknologi sebagai sumber daya utama untuk meningkatkan pelayanan di sebuah organisasi menjadi sebuah keharusan. Pada dasarnya Kepala Desa Semaya dan Kepala Desa Pegiringan sadar akan manfaat yang dapat diperoleh dari penerapan $e$ government di level Pemerintah Desa.

Melalui e-government tuntutan akan transparansi publik juga dapat diwujudkan oleh Pemerintah Desa. Egovernment hadir sebagai sarana 
Jurnal Administrasi Negara

ISSN : 2598-4039 (Online)

ISSN : 2302-2231 (Print)
Subhan, Arif Budy Pratama

Universitas Tidar Magelang pengawasan bagi masyarakat desa terhadap penyelenggaraan pemerintahan baik di Desa Semaya maupun di Desa Pegiringan. Bagi Desa Semaya pengembangan website desa akan terus dilakukan sehingga penggunaanya tidak hanya sebagai penyedia informasi akan tetapi dapat memberikan pelayanan online seperti pengurusan surat pengantar SKCK, KTP dan layanan lainnya. Harapannya inovasi-inovasi pelayanan melalui website akan terus bertambah.
Sedangkan bagi Pemerintah Desa Pegiringan, komitmen nyata ditunjukkan melalui alokasi anggaran tahun 2019 untuk dapat menambah perangkat yang dirasa masih kurang maksimal. Penambahan perangkat tersebut juga untuk dapat mendukung terwujudnya taman bacaan online yang dapat diakses oleh masyarakat setempat. Selain itu, penganggaran tersebut juga menjadi bagian untuk dapat mewujudkan ide Desa Pemerintah Desa Pegiringan untuk dapat menjadi Pegiringan Smart Village.

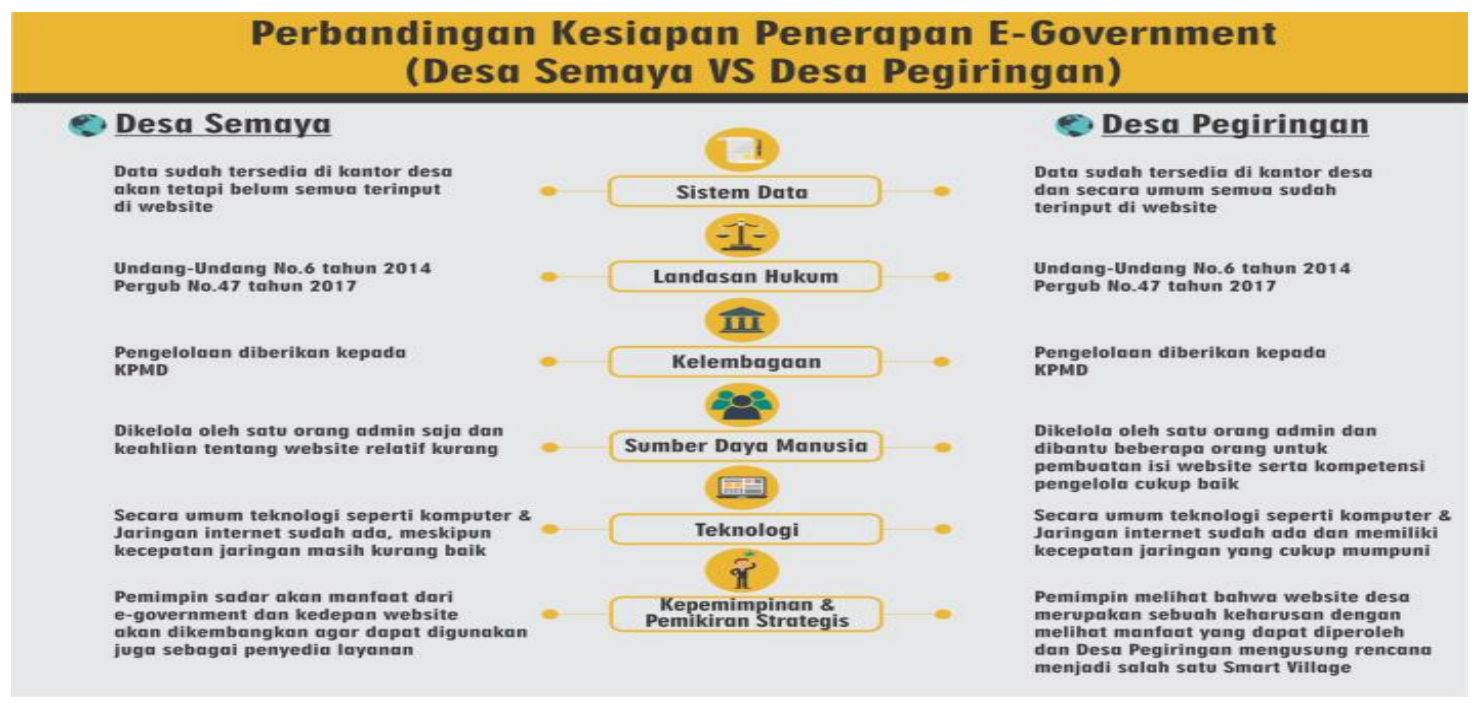

Gambar 1: Perbandingan kesiapan penerapan e-government

Apa yang dapat dipelajari oleh Pemerintah Desa Semaya?

Keberhasilan Desa Pegiringan dalam menerapkan e-government pada level pemerintah desa tentunya dapat menjadi rujukan bagi Pemerintah Desa Semaya untuk dapat mengambil beberapa pelajaran. Dengan demikian penerapan $e$ government di Desa Semaya menjadi lebih baik. Beberapa pelajaran yang dapat diambil diantaranya.

Pertama, sumber daya manusia. Masih kurangnya pengetahuan admin website di Desa Semaya menyebabkan pengelolaan tidak berjalan maksimal. Sehingga penerapan e-government tidak berkembang. Kurangnya keahlian dalam mengelola e-government sebenarnya dapat diatasi melalui beberapa pelatihan. Selain itu, ketergantungan terhadap pelatihan yang dilaksanakan oleh Pemerintah Daerah juga harus dihindari. Seperti yang sudah dicontohkan oleh Pemerintah Desa Pegiringan dimana mereka mampu menjalin komunikasi yang baik dengan PUSPINDES dan memperoleh pembelajaran diluar dari kegiatan pelatihan yang sudah dijadwalkan. Selain itu, kompetensi pengelola dapat ditingkat melalui kerjasama pelatihan dengan komunitas atau organisasi yang bergerak dibidang 
teknologi informasi. Dengan demikian, literacy tentang pengembangan teknologi informasi baik dari pengelola website maupun perangkat desa yang lain relatif menjadi lebih baik.

Kuantitas pengelola website juga sebenarnya tidak bisa hanya dibebankan terhadap satu orang. Pembagian tugas dalam penerapan e-government cukup penting seperti yang dilaksakan oleh Pemerintah Desa Pegiringan. Dalam hal ini ada bagian admin panel yang mengembangkan e-government dan penginputan data serta bagian lain yang bertugas untuk pembuatan konten website desa sehingga masing-masing pengelola dapat menjalankan tugasnya secara maksimal. Sistem pengelolaan tersebut harusnya juga dapat diterapkan pada website desa Semaya. Perlu adanya model pengelolaan baru dimana operator utama dapat dijadikan sebagai super admin yang fokus untuk mengembangankan e-government sedangkan beberapa admin yang lain bertugas untuk membuat konten dari website desa. Pembagian tugas pokok dan fungsi yang jelas tentunya dapat mempermudah proses penerapan dan pengembangan e-government ini.

Kedua, pembangunan infrastruktur teknologi. Secara umum infrastruktur teknologi seperti perangkat keras dan jaringan sudah tersedia di Kantor Desa Semaya. Akan tetapi, kurangnya kecepatan jaringan yang mumpuni menjadi hambatan pengelolaan dan masih perlu adanya perbaikan. Seperti halnya di Desa Pegiringan dimana kecepatan jaringan cukup berperan terhadap arus informasi serta layanan melalui website desa. Hal ini juga harus diadopsi pula oleh Pemerintah Desa Semaya sehingga pengelolaan e-government juga relatif semakin mudah. Pembangunan jaringan hotspot area dibeberapa tempat diperlukan untuk membuka akses bagi masyarakat berpartisipasi terkait dengan pengawasan pembangunan pedesaan. Dengan demikian, check and balanced antara pemerintah dengan masyarakat dapat terwujud.

Ketiga, Kepemimpinan.

Keberhasilan Pemerintah Desa Pegiringan dalam mendapatkan penghargaan dari implementasi $e$ government tentunya tidak dapat lepas dari kemauan dan komitmen pemimpin dalam mewujudkan e-gov. Peran pemimpin sebagai pengarah bagi organisasi mampu dijalankan dengan cukup baik sehingga tujuan penerapan $e$ government dapat dirasakan. Gagasangagasan untuk mengembangkan $e$ government menjadi bukti bahwa Pemerintah Desa Pegiringan secara konsisten berinisiatif memperbaiki sisi penyelengaraan pemerintahan. Bahkan Pemerintah Desa Pegiringan secara khusus mengalokasikan anggaran melalui APBDes untuk terus menjaga keberlangsungan penerapan $e$ government.

Komitmen dan gagasan ini harusnya menjadi referensi bagi Pemerintah Desa Semaya. Kemudian, alokasi anggaran untuk proses pembangunan infrastruktur penunjang yang lebih mumpuni dalam penerapan e-government masih menjadi perhatian penting Pemerintah Desa Semaya. Agar kedepannya asas kemanfaatan e-government bagi masyarakat benar-benar dapat diwujudkan oleh Pemerintah Desa Semaya.

\section{Diskusi}

Hasil penelitian tentang kesiapan penerapan e-government pada level pemerintah desa dalam aspek sumber daya manusia menemukan bahwa kualitas dan kuntitas dari sumber daya 
Jurnal Administrasi Negara

ISSN : 2598-4039 (Online)

ISSN : 2302-2231 (Print)
Subhan, Arif Budy Pratama

Universitas Tidar Magelang manusia terhadap pengoperasian website menyebabkan kurang maksimalnya penerapan e-government di Pemerintah Desa Semaya. Hasil penelitian ini mendukung temuan dari Rindengan, \& Karouw (2017) dengan menggunakan metode kuantitatif melakukan analisa kesiapan kota cerdas di Pemerintah Kota Manado. Hasil pengukurannya menunjukkan untuk sektor sumber daya manusia dirasa masih belum siap karena beberapa pegawai tidak memiliki latar belakang pendidikan informasi dan teknologi (IT) serta kurang memahami penggunaan aplikasi yang sudah diluncurkan pemerintah sehingga diperlukan evaluasi kedepannya.

Kemiripan hasil penelitian dalam aspek SDM juga ditemukan penulis dalam hasil penelitian Mayowan (2017). Penelitiannya menemukan masih kurangnya ketersediaan sumber daya manusia yang dapat mengoperasikan IT sehingga menjadi hambatan penerapan IT di Kabupaten Lamongan. Temuan dari penelitian-penelitian ini menekankan pentingnya sumber daya manusia baik secara kualitas maupun kuantitas dalam implementasi e-government.

Selain itu, hasil lain riset ini dalam aspek kelembagaan menemukan belum adanya pembentukan unit khusus yang dapat mengkoordinasi, memimpin penerapan e-government di Pemerintah Desa juga mempunyai kemiripan hasil riset dari Latif, Wahyu, \& Surjono (2012) tentang penilaian e-audit readiness pada Badan Pemeriksa Keuangan (BPK) RI Perwakilan Provinsi Banten dengan studi kuantitatif yang menemukan persoalan sama dimana belum ada bagian khusus sebagai pengelola IT. Dalam penelitian tersebut juga ditemukan masih kurangnya pemahaman pegawai terhadap aplikasi sehingga masih diperlukan pelatihan yang masif.
Disamping kelembagaan, aspek kepemimpinan mempunyai peran penting dalam penerapan e-government. Pemikiran atau gagasan dari pemimpin dalam upaya mewujudkan serta mengembangkan e-government turut berperan dalam keberhasilan Pemerintah Desa Pegiringan untuk memperoleh beberapa penghargaan terkait dengan implementasi website desa. Hasil penelitian ini juga memperkuat penelitian yang dilakukan oleh Wahid (Wahid, 2007) tentang pelajaran dari implementasi e-government di Sragen yang menunjukkan bahwa kepemimpinan yang kuat dengan visi yang jelas sangat membantu keberhasilan implementasi $e$ government.

Dukungan pemimpin yang kuat dibutuhkan untuk mengubah kultur organisasi menuju modernisasi dalam penyediaan layanan publik. Kemudian hasil serupa juga terdapat pada penelitian Napitupulu (2015) dimana faktor kepemimpinan menjadi salah satu elemen keberhasilan Pemerintah Kota Bogor dalam menerapkan e-government dan mendapat beberapa penghargaan.

Dari aspek metode, studi kualitatif yang digunakan berkontribusi terhadap beberapa penelitian yang pernah dilakukan. Beberapa penelitian tersebut menggunakan studi kuantitatif yang hanya melihat atau memotret fenomena mengenai kesiapan penerapan $e$ government di sebuah organisasi publik. Sedangkan penelitian secara kualitatif dengan banyaknya sumber data yang digunakan memungkin peneliti untuk dapat memahami sebuah fenomena secara mendalam. Kemudian penggunaan studi perbandingan yang digunakan penulis untuk menganalisis kesiapan penerapan $e$-gov di kedua desa (Semaya dan Pegiringan) tentunya menjadi 
pembaharuan dalam penelitian tentang kesiapan penerapan e-government.

\section{PENUTUP}

Berdasarkan perspektif kesiapan dari Heeks (2001) maka poin-poin penting yang harus disiapkan agar pelaksanaan $e$ government dapat berjalan dengan baik adalah sistem data, landasan hukum, kelembagaan, sumber daya manusia, infrastruktur teknologi serta kepemimpinan dan pemikiran strategis.

Desa yang mempunyai kinerja yang relatif baik dalam menerapkan $e$ government mempunyai karakteristik sebagai berikut. Pertama, sistem data yang benar-benar dapat mendukung tersedianya berbagai informasi dalam implementasi e-government. Artinya pencatatan data yang ada mampu menyediakan data dengan lengkap.

Kedua, landasan hukum yang kuat sehingga sifat hukum yang memaksa mengharuskan sebuah institusi mengimplementasikan e-government. Pemahaman terhadap landasan hukum tersebut juga sangat diperlukan untuk menciptakan kesatuan tujuan.

Ketiga, kelembagaan. Ketersediaan unit tertentu yang fokus untuk mengembangakan e-government sangat penting karena unit ini yang akan memimpin dan mengkoordinasikan pengembangan e-government .

Keempat, aspek sumber daya manusia yang lebih baik untuk mengelola $e$ government baik dari segi kuantitas maupun kualitas. Kelima, mempunyai infrastruktur teknologi yang cukup mumpuni, mulai dari perangkat komputer serta jaringan internet yang baik.

Pembangunan infrastruktur jaringan internet bagi masyarakat juga diperlukan untuk memberikan kemudahan akses bagi masyarakat. Kemudian mempunyai aspek kepemimpinan dan pemikiran strategis dimana pemimpin benar-benar memiliki komitmen, kemauan kuat serta gagasan untuk dapat menerapkan dan mengembangkan e-government. 
Jurnal Administrasi Negara

ISSN : 2598-4039 (Online)

ISSN : 2302-2231 (Print)
Subhan, Arif Budy Pratama

Universitas Tidar Magelang

\section{REFERENSI}

Abadi, T. W., Prajarto, N., \& Guntoro, B. (2014). Performance E-Government Untuk Peningkatan Partisipasi Masyarakat Dalam Pembangunan Infrastruktur Di Kabupaten Sidoarjo. Jurnal Kawistara, 4(3), 237-248. https://doi.org/10.22146/kawistara.6 379

Alaaraj, H., \& Ibrahim, F. W. (2014). An Overview and Classification of EReadiness Assessment Models. International Journal of Scientific and Research Publications, 4(12), 1-5. Retrieved from http://www.ijsrp.org/research-paper1214.php?rp=P363500

Alshehri, M., \& Drew, S. (2010). Implementation of e-Government: Advantages and Challenges. International Conference E-Activity and Leading Technologies 2010, 24(3), 79-88. https://doi.org/10.1109/ICoIA.2013. 6650243

Aprizal, \& Purba, J. R. T. (2013). Akuntabilitas Pelayanan Publik dalam Pelaksanaan E-Procurement di Kota Pangkalpinang. JKAP (Jurnal Kebijakan Dan Administrasi Publik), 17(1), 15-28.

Beig, L., Montazer, G. A., \& Ghavamifar, A. (2007). Adoption A Proper Tool For E-Readiness Assessment In Developing Countries (Case Studies: Iran, Turkey And Malaysia). Journal of Knowledge Economy \& Knowledge Management, II(I), 54-69.

Creswell, J. W. (2013). Research Design Pendekatan Kualitatif, Kuantitatif dan Mixed. Yogyakarta: Pustaka Pelajar.

Heeks, R. (2001). Understanding EGovernance for Development. IGovernment Working Paper Series,
1-25. Retrieved from http://unpan1.un.org/intradoc/groups /public/documents/NISPAcee/UNP AN015484.pdf

Kodarisman, R., \& Nugroho, E. (2013). Evaluasi Penerapan Sistem Informasi Manajemen Kepegawaian (SIMPEG) di Pemerintah Kota Bogor. JNTETI, 2(2), 24-32.

Kurniasih, D., Fidowaty, T., \& Sukaesih, P. (2013). Pengaruh Implementasi Kebijakan E-Government Terhadap Kinerja Aparatur Kota Cimahi. Sosiohumaniora, 15(1), 6-14.

Latif, A., Wahyu, W., \& Surjono. (2012). Penilaian E-Audit Readiness dengan Pendekatan Framework STOPE pada Badan Pemeriksa Keuangan ( BPK ) RI Perwakilan Provinsi Banten. Jnteti, 1(2), 1-9.

Lou, E. C. . (2010). E-Readiness: How Ready Are Uk Construction Organizations To Adopt It. Procs 26th Annual ARCOM Conference, 947-956.

Mayowan, Y. (2017). Penerapan Teknologi Informasi Dan Komunikasi Di Desa ( Studi Kasus di Kabupaten Lamongan ). Profit Jurnal Administrasi Bisnis, 10(1), 14-23.

https://doi.org/http://dx.doi.org/10.9 876/10.9876/VOL1ISSN1978-743X

Napitupulu, D. (2015). Kajian Faktor Sukses Implementasi E-Government Studi Kasus: Pemerintah Kabupaten Bogor. Jurnal Sistem Informasi, 5(3), 229-236. https://doi.org/https://doi.org/10.240 89/j.sisfo.2015.03.009

Pegiringan.desa.id. Pegiringan.desa.id Raih ID Website Award PANDI 2018. Retrieved September 30, 2018, from https://pegiringan.desa.id/pegiringan 
Jurnal Administrasi Negara

ISSN : 2598-4039 (Online)

ISSN : 2302-2231 (Print)
Subhan, Arif Budy Pratama

Universitas Tidar Magelang -id-raih-id-website-award-pandi2018/

Pratama, A. B. (2017a). Agencification in Asia : Lessons From Thailand, Hong Kong, and Pakistan. JKAP (Jurnal Kebijakan Dan Administrasi Publik), 21(1), 40-54.

Pratama, A. B. (2017b). Citra Pemerintah di Era Digital Tipologi dan Manajemen Reputasi. Yogyakarta: Gava Media.

Rahman, A. (2011). Evaluasi Kesuksesan E-Government Studi di Kabupaten Sleman dan Kabupaten Tulungagung. Jurnal Akuntansi Dan Auditing Indonesia, 15(2), 190-203.

Rahmawati, R., \& Firman, F. (2017). Analisis Impelementasi Kebijakan Aplikasi Qlue Di Wilayah Jakarta Utara. Aristo, 5(2), 386-404. https://doi.org/10.24269/aristo.v/1.2 017.10

Sukarso, P., Rokhman, A., \& Rosyadi, S. (2017). Faktor yang Berpengaruh terhadap Kesiapan BPK RI Sulawesi Tenggara dalam "E-Audit." MIMBAR, Jurnal Sosial Dan Pembangunan, 31(2), 283. https://doi.org/10.29313/mimbar.v31 i 2.1352

Susanto, A. (2011). Analisis Citizen EReadiness Dalam Pengembangan
Desa Berbasis Teknologi Informasi. Masyarakat Telematika Dan Informasi : Jurnal Penelitian Teknologi Informasi Dan Komunikasi, 2(1), 61-74. Retrieved from

https://mti.kominfo.go.id/index.php/ mti/article/view/19/18

Wahid, F. (2007). Pelajaran dari Implementasi E-Government di Sragen. Seminar Nasional Aplikasi Teknologi Informasi (SNATI ), 3537.

https://doi.org/10.1017/CBO978110 7415324.004

Widowati, D. P. D. (2018). Survei PBB 2018: Peringkat E-Government Indonesia. Retrieved November 13, 2018, from http://bpptik.kominfo.go.id/surveipbb-2018-peringkat-e-governmentindonesia/

Wijaya, S. W., \& Surendro, K. (2006). Kajian Teoritis: Model EGovernment Readiness Pemerintah. Seminar Nasional Aplikasi Teknologi Informasi 2006 (SNATI 2006), 25-28. https://doi.org/19075022 